\title{
Indian Telecom Sector - Witnessing a Revolution
}

\author{
Dr.H.R.Uma and Dr.A.C. Kiran Kumar
}

\begin{abstract}
According to the Human Development Report, 2000, the contribution of services to the GDP was $45 \%$. In the year 2010, service industry accounts to 55\% of countries GDP while the industrial and agricultural sectors contribute $28 \%$ and $17 \%$ respectively. As a result of this structural economic transformation, it has become apparent that we focus more on services and at a micro level we need to develop expertise in managing these service companies. In the backdrop of changing global scenario, Indian telecom sector is witnessing a tremendous growth and increased up to date services at a cheaper rate have certainly brought in tremendous revolution in the society
\end{abstract}

\section{Introduction}

According to the Human Development Report, 2000, the contribution of services to the GDP was $45 \%$. In the year 2010, service industry accounts to 55\% of countries GDP while the industrial and agricultural sectors contribute $28 \%$ and $17 \%$ respectively. As a result of this structural economic transformation, it has become apparent that we focus more on services and at a micro level we need to develop expertise in managing these service companies. In the backdrop of changing global scenario, Indian telecom sector is witnessing a tremendous growth and increased up to date services at the cheaper rates have certainly brought in tremendous revolution in the society. The common man, artisans, agricultural labours, vendors and workers from every walk of life are comfortably using the services provided by telecom companies. While services have touched almost every aspect of our existence, the devices and services which are dependent on mobile network technologies are very common in our daily life (Bala subramanium, Pererson et al. 2002).

India has one of the world's largest telecommunication networks. The telecom story continues to be the best evidence of the efficacy of the reforms process. In just few years, the number of mobile subscribers has gone from just about one million to 500 million, a subscriber base that only four other countries China, the USA, Japan, UK and Russia can boast of. None can doubt the correlation between this explosive growth in numbers and the steep decline in the cost of the mobile phone and of its usage. Effective tariffs have dropped from over Rs 14 a minute to $1 / 2$ a Pisa per second and still boasting to become much lower, bringing the phone within the reach of people even below the middle-class.

The telecom industry in India is undoubtedly the showpiece of reforms that have been initiated since 1991 in the country. From an almost monopoly till the early 1990s when mobile call rates were as high as Rs 16 per minute, the telecom space has evolved into a vibrant industry with at least half a dozen players and call rates as low as $1 / 2$ paisa per second at the last count. However, in some ways the reforms have proved to be successful. India currently has the lowest Average Revenue per Users (ARPUs) across the world, low enough to raise questions on the sustainability of the current business model. Additionally, the recent auction for licenses that took place in 2007 has prompted a further spate of entry and a further round of price wars.

Indian Telecom Industry has witnessed explosive growth in mobile sector. Number of subscribers has increased substantially over past few years leading to 525 million of subscribers in the year 2009 with $51 \%$ average annual growth. The number is expected to grow at 44\% annual rate to 760 million in the year 2010 . Mobile penetration currently stands at $45 \%$ and is expected to reach at $64 \%$ by the end of 2010 . Traditionally, the mobile market in India has been dominated by basic Global System for Mobile (GSM) and Code Division Multiple Access (CDMA) handsets, but with the growing popularity of internet and related services over mobile and with the rollout of $3 \mathrm{G}$, the popularity of smart phone is expected to increase drastically.

The difference in growth that we see is typical of the difference between a mature market in developed countries like the USA, European countries and a developing market like India. As to why the Indian market is growing faster than other developing countries, it is evident that it has been due to both innovative private operators and the success of right Government policy and fair regulation, apart from a large available population to be served. The key milestone in this respect was the New Telecom Policy of 1999 (NTP 99). That was the time when the Government realized that a fixed license fee, which was based on exorbitant bids placed for licenses, would not work and shifted to revenue share based license fee. At that time just to cover the license fee the operators would have had to generate Rs500 per customer per month. This was a significant drag on the growth in the number of subscribers.

The Government also put in place the eco-system by creating good institutions like the Telecom Regulatory Authority of India (TRAI) and Telecom Disputes Settlement and Appellate Tribunal (TDSAT) 
which were necessary to attract private investments in the sector. As the duopoly structure stabilized, Government issued third and fourth licenses promoting competition. The Government then came up with Unified Access Service Licensing (UASL) in 2003, which made it possible for TATA and Reliance to provide mobile services through CDMA platform originally built for basic services, fuelling competition further. Having said that, the role played by the innovativeness of private operators in a highly competitive environment, cannot be underestimated. Given the large variations in income, they came up with plans like lifetime schemes, pay in instalments, chota recharge, Bonus packs; international roaming cards so on and so forth.

\section{Tele-Communication In India:}

Indian Telecommunication Industry, with about 525.65 million mobile phone connections is the third largest telecommunication network in the world and the second largest in terms of number of wireless connections (IANS, 2009; TRAI, 2009). For the past decade or so, telecommunication activities have gained momentum in India. Efforts have been made from both Governmental and non-Governmental platforms to enhance the infrastructure. The idea is to help modern telecommunication technologies to serve all segments of India's culturally diverse society, and to transform it into a country of technologically aware people. Telephone service started in 1881 in India, with 5 telephone exchanges and 245 connections. Today there are more than 35,000 Telephone exchanges in the country with around 20 million connections. The network is maintained by around 4.3 Lakhs employees who work 24 hours a day, 7-day a week and 365 days a year. (BSNL, 2003)

A large population, low telephony penetration levels at the earlier day, and a rise in consumers' income and spending to strong economic growth have helped make India the fastest-growing telecom market in the world. The first and largest operator is the state-owned incumbent BSNL formed in October 2000, which is also the 7th largest telecom company in the world in terms of its number of subscribers (BSNL). Subsequently, after the telecommunication policies were revised to allow private operators, companies such as Bharthi Airtel, Vodafone (formerly known as Hutch), Idea (took over Spice), Tata Indicom, Aircel, Tata Docomo, MTS, Uninor so on and so forth have entered the market.

According to Telecom Regulatory Authority of India (TRAI), India added 16.67 million wireless subscribers--GSM, CDMA and FWP combined--taking the total wireless subscriber base to 488.4 million (ET, 2009), which reveals the rapid growth of the India's mobile market.

The Telecom Industry in India is in its growth stage (Tso, 2002) ${ }^{1}$. Telecom is one area in India where significant improvements have happened (Thomas, 2007) ${ }^{2}$. Now the private operators also are providing services which are giving rise to more choice (Sprague, 2008) ${ }^{3}$.

In 1991, India had just five million telephone subscribers and in 2007 the telecom base crossed 250 million (Kaushik, 2007). As at the end of October 2008, there were 363.95 million subscribers. Teledensity too which was below one telephone per 100 population has now risen sharply to above 30 . What has happened over the past decade in Telecom Sector in India is a revolution of sorts. In April 2008, India overtook the US as the second largest wireless market. India is projected to become the second largest telecom market globally by 2010. Overall, tele-density has touched 21.85 per cent against the target of 15 per cent by 2010; growth has, thus, far outpaced projections (Kaushik, 2007).

\section{Significant Contribution Of Telecommunication And Cellular Sector:}

Among a variety of infrastructural goods, telecommunications is special in one respect: the application of modern telecommunications technology is an extremely important ingredient in the rapid growth of India's economy. In this sense, telecom should be viewed as an essential "factor of production" which is part of the process of transforming the efficiency of utilization of India's labour and capital (Mohanasundaram) ${ }^{5}$.

For instance, on considering the world mobile-telephony, we can witness the tremendous growth and individual adaptability with reference to developed and developing nations. From table it is found that only three people among 100 were found using mobile-telephony services in the year 2000 compared to that of 33 people in the

\footnotetext{
${ }^{1}$ Tso, C.-D. (2002, June). Evolution of Cellular Telecom Equipment Industry: Technology-Driven or Policy-Stimulated. Indian Journal of Economics and Business, 111-33.

${ }^{2}$ Thomas, P. (2007). Telecom Musings: Public Service Issues in India. Emerald Group Publishing Limited , 97-107.

${ }^{3}$ Sprague, C. (2008). Telecommunications in Business. Research Starters Business , 1-3.

${ }^{4}$ Kaushik, M. (2007, November 18). Telecom base crosses 250 million. Buiness Today

${ }^{5}$ Mohanasundaram, V. Significant Contribution of Telecommunication Sector. In P. G. P. Jegadish Gandhi, Services sector in the Indian Economy. New Delhi: Deep \& Deep Publications Pvt. Ltd.
} 
year 2008. When compared with the neighbouring nations like China, Sri Lanka and other developing nations, it is found that India has tremendous growth opportunities where majority of the market can be penetrated.

I. World Mobile And Fixed-Line Telephone Subscribers (Per 100 People) For The Period Of 2000- 2008

\begin{tabular}{|l|c|c|c|c|c|c|c|c|c|}
\hline & 2000 & 2001 & 2002 & 2003 & 2004 & 2005 & 2006 & 2007 & 2008 \\
\hline China & 18.22278 & 25.56811 & 32.81998 & 41.34586 & 49.88755 & 57.05604 & 63.22131 & 69.27334 & 74.13553 \\
\hline India & $\mathbf{3 . 5 4 4 8 7 8}$ & $\mathbf{4 . 3 6 5 8 4 5}$ & $\mathbf{5 . 1 8 9 5 7 5}$ & $\mathbf{7 . 1 1 1 0 5 8}$ & $\mathbf{9 . 1 1 5 1 3 3}$ & $\mathbf{1 2 . 8 1 9 1 7}$ & $\mathbf{1 8 . 6 3 5 6}$ & $\mathbf{2 4 . 2 7 4 2}$ & $\mathbf{3 3 . 7 5 4 5 5}$ \\
\hline Sri Lanka & 6.399655 & 7.952636 & 9.589932 & 12.16511 & 16.45461 & 23.41758 & 36.69201 & 53.60094 & 72.08135 \\
\hline Germany & 119.7202 & 131.7285 & 136.7116 & 144.2108 & 152.513 & 162.5597 & 170.0146 & 181.7668 & 191.113 \\
\hline $\begin{array}{l}\text { United } \\
\text { Kingdom }\end{array}$ & 133.5993 & 136.8022 & 141.5286 & 149.0824 & 157.4225 & 165.2763 & 171.4819 & 176.4621 & 180.0402 \\
\hline United States & 107.0237 & 112.2732 & 115.0262 & 118.3395 & 123.704 & 131.3302 & 137.1685 & 139.8774 & 139.826 \\
\hline
\end{tabular}

Source: International Telecommunication Union, World Telecommunication Development Report and database, and World Bank estimates.

\section{Graph : World Mobile And Fixed-Line Telephone Subscribers For The Period Of 2000-08}

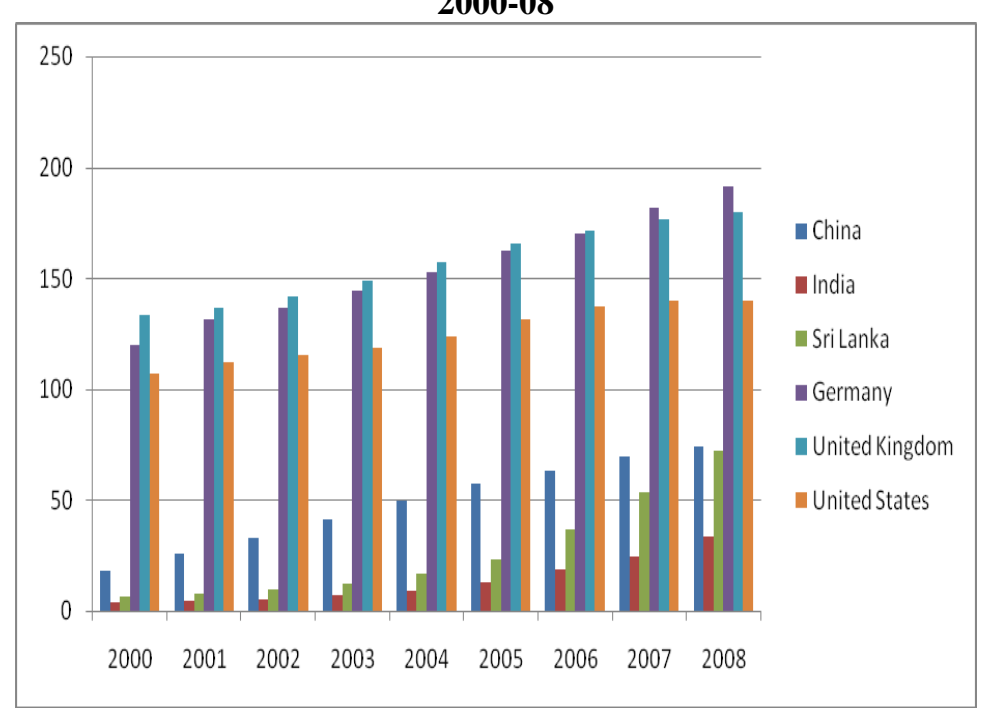

Graph : Trend Of World Mobile And Fixed-Line Telephone Subscribers

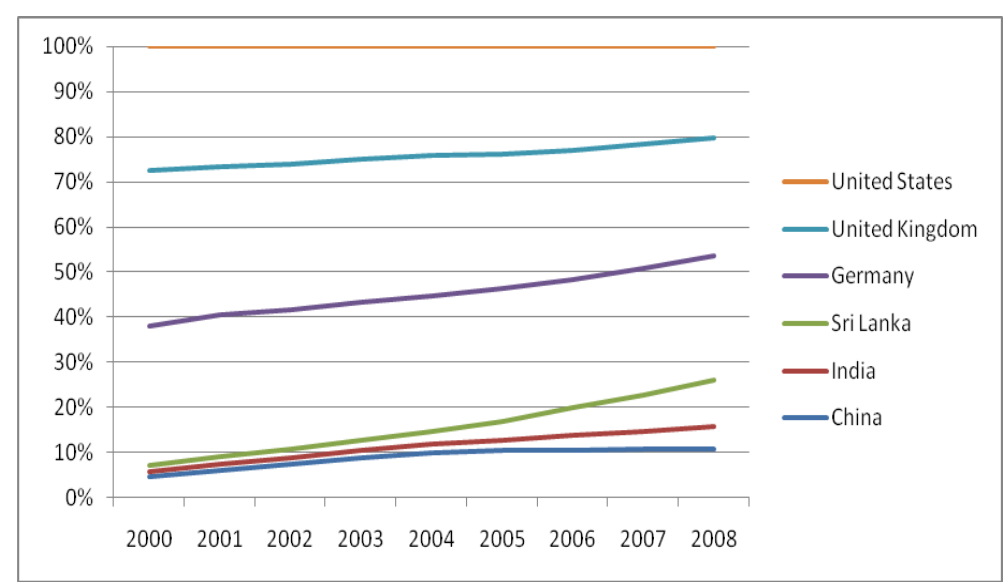

From the above figure we can see the dramatic increase of mobile cellular subscrption of developing and developed nations. In the year 2000 the total mobile cellular subscription was 719 million, in the year 2005 it was 2.2 billion and by the end of year 2010 it is estimated to be 5.3 billion.

Figure: Mobile Cellular Subscriptions By Level Of Development 

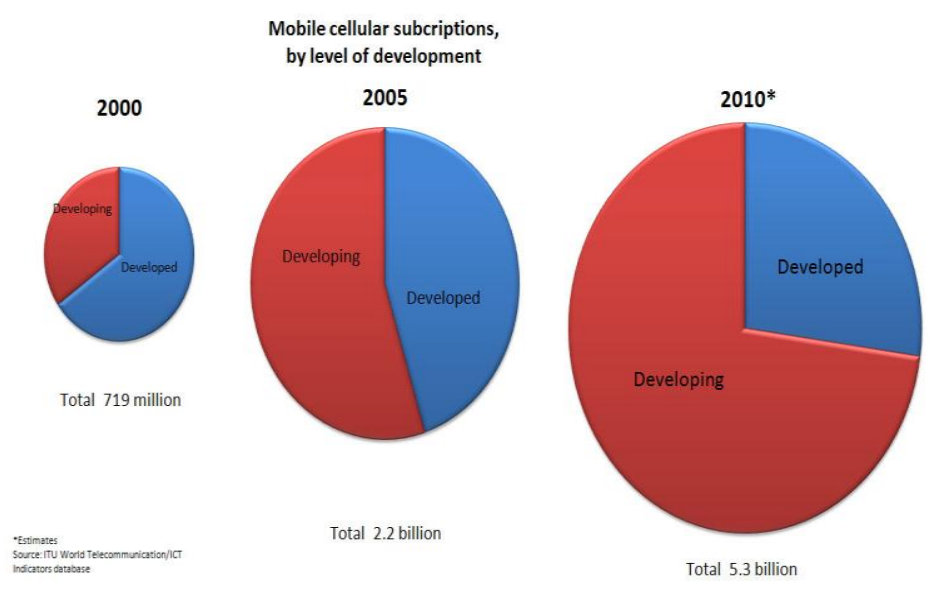

From the above figure it is witnessed that in the year $2003,61 \%$ of the world's population was covered by the mobile cellular signals, where as in the year 2009 about $90 \%$ of the world's population has been covered by the mobile cellular signal. This reveals the increase in demand for mobile cellular telephony among the developing and developed nations.

Figure : Mobile Cellular Subscriptions Per 100 Inhabitants, 2000-10

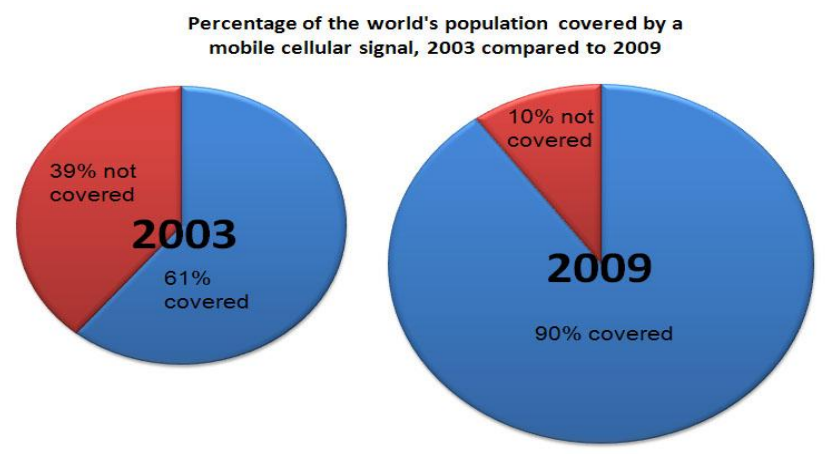

Mobile cellular subscriptions per 100 inhabitants, 2000-2010

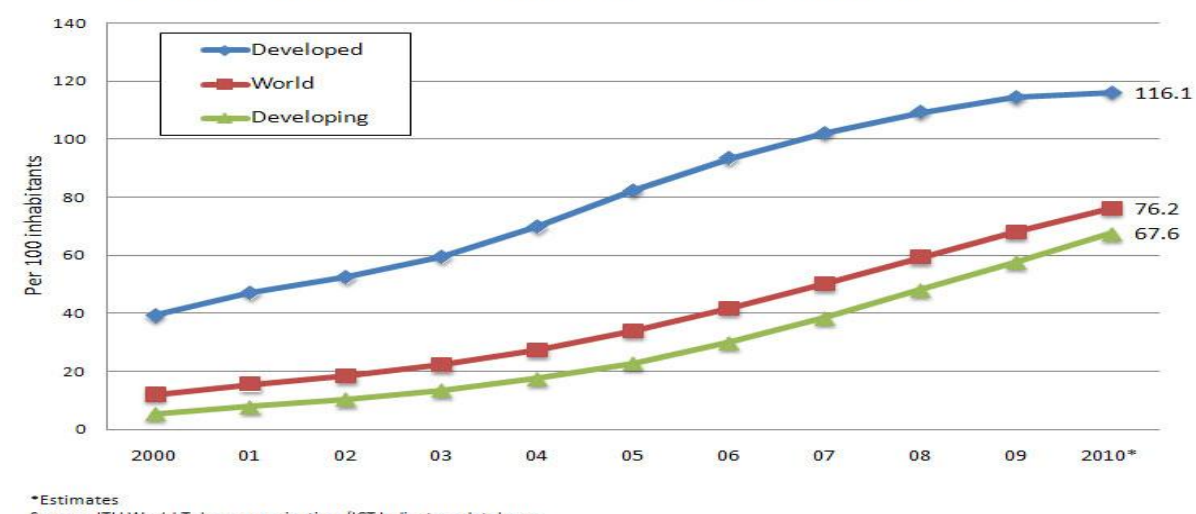

From the above figure we can analyze the trend in the growth of mobile cellular subscribers base per 100 inhabitants with reference to developed and developing nations across world for the period of ten years i.e., from year 2000 to 2010. From the above figure we can see that the overall mobile subscription across world is 76.2 per 100 inhabitants. But when compared with developed and developing nations it is 116.1 and 67.6 per 100 inhabitants respectively. 


\section{Growth In Subscriber Base Of Cellular Users In India:}

Inspite of many operators and various flexible schemes offered by the cellular operators in India, it has become very difficult for the marketers to capture the major chunk of the market share. When compared India with rest of the world, we can witness the snail pace of adoption in getting used to cellular services.

Growth in subscriber base of cellular users in India

\begin{tabular}{|c|c|c|c|c|c|c|c|c|c|c|}
\hline & BSNL & MTNL & Bharti & $\begin{array}{l}\text { Vodafone } \\
\text { Essar }\end{array}$ & IDEA & BPL & Aircel & Spice & $\begin{array}{l}\text { Reliance } \\
\text { Telecom }\end{array}$ & All India \\
\hline $\begin{array}{r}\text { Jan- } \\
05 \\
\end{array}$ & 8673533 & 689521 & 10241709 & 7431318 & 4879663 & 2495065 & 1686010 & 1500003 & 1052768 & 38649590 \\
\hline $\begin{array}{r}\text { Jan- } \\
06 \\
\end{array}$ & 15082393 & 1630674 & 17175160 & 13913013 & 6732541 & 1334272 & 2993059 & 1717478 & 2456084 & 63034674 \\
\hline $\begin{array}{r}\text { Jan- } \\
07 \\
\end{array}$ & 24442364 & 2498234 & 33731954 & 24414358 & 13071949 & 1062255 & 4802346 & 2519927 & 3876216 & 110419603 \\
\hline $\begin{array}{r}\text { Jan- } \\
08 \\
\end{array}$ & 33748599 & 3013199 & 57417625 & 41145413 & 21954685 & 1256534 & 9933815 & 3942828 & 6001978 & 178414676 \\
\hline $\begin{array}{r}\text { Jan- } \\
09 \\
\end{array}$ & 42673357 & 4003807 & 88382758 & 63340024 & 40016153 & 2007303 & 16761745 & $*$ & 10744953 & 267930100 \\
\hline $\begin{array}{r}\text { Jan- } \\
10 \\
\end{array}$ & 61004235 & 4697033 & 124619205 & 97229874 & 62143629 & - & 34860993 & $*$ & 16311206 & 407914988 \\
\hline
\end{tabular}

-Data not available * Spice was taken over by Idea Source: COAI

From the above table it can be witnessed that the all India cellular subscriber base has drastically increased from 3.8 million to 40.7 million showing the positive inclination to adopting towards mobile cellular services. Inspite of both public and private cellular players offering various services in the market only minority of the population is been benefited.

From the graph , it is seen that Bharti Airtel is having major market share compared to that of other private and public cellular service operators across the nation.

Table: Growth of Market Share Of Major Cellular Operators In India (In \%)

\begin{tabular}{|c|c|c|c|c|c|c|c|c|c|}
\hline & BSNL & MTNL & Bharti & $\begin{array}{l}\text { Vodafone } \\
\text { Essar }\end{array}$ & IDEA & BPL & Aircel & Spice & $\begin{array}{l}\text { Reliance } \\
\text { Telecom }\end{array}$ \\
\hline Jan-05 & 22.44 & 1.78 & 26.50 & 19.23 & 12.63 & 6.46 & 4.36 & 3.88 & 2.72 \\
\hline Jan-06 & 23.93 & 2.59 & 27.25 & 22.07 & 10.68 & 2.12 & 4.75 & 2.72 & 3.90 \\
\hline Jan-07 & 22.14 & 2.26 & 30.55 & 22.11 & 11.84 & 0.96 & 4.35 & 2.28 & 3.51 \\
\hline Jan-08 & 18.92 & 1.69 & 32.18 & 23.06 & 12.31 & 0.70 & 5.57 & 2.21 & 3.36 \\
\hline Jan-09 & 15.93 & 1.49 & 32.99 & 23.64 & 14.94 & 0.75 & 6.26 & $*$ & 4.01 \\
\hline Jan-10 & 14.96 & 1.15 & 30.55 & 23.84 & 15.23 & - & 8.55 & $*$ & 4.00 \\
\hline
\end{tabular}

-Data not available * Spice was taken over by Idea Source: COAI

From the above table we can understand how the major cellular operators were able to capture the market share with reference to pooling the consumers for getting them adapted to their various offerings. It can be witnessed that the market share of BSNL was $22.44 \%$ in the year 2005 and now it has lost its share to other cellular operators with present share of $14.96 \%$. It may also be found out that all the private cellular operators are gaining the market share year after years except BPL and Spice.

\section{Graph : Growth of market share of major cellular operators in India (in \%)}

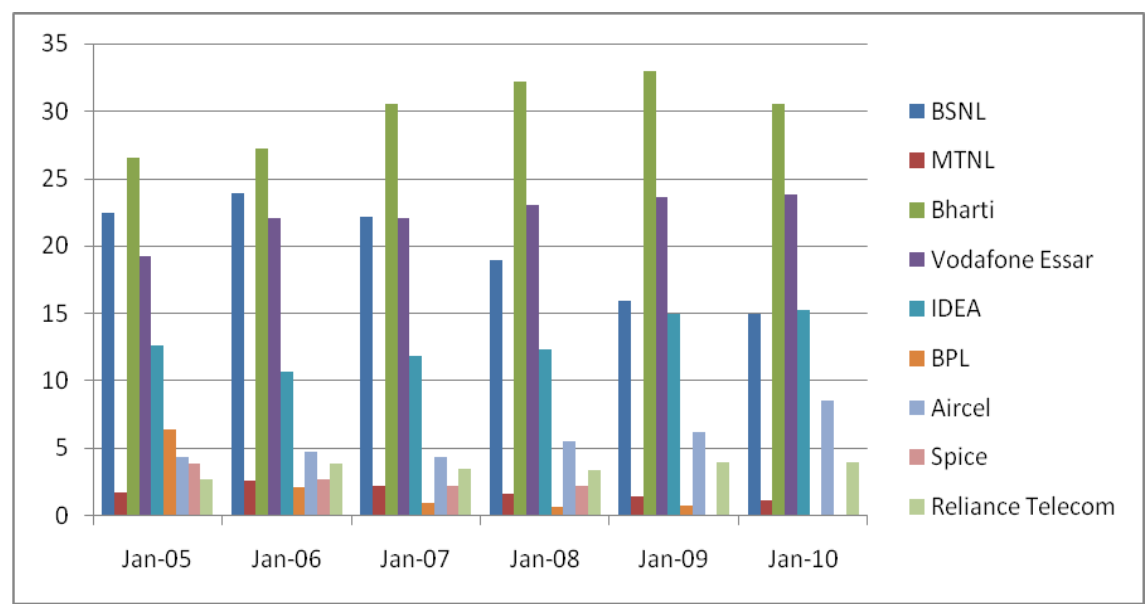




\section{Conclusion:}

LDCs are experiencing fastest growth in telecom network. In the mid-90s, growth in total telephone subscribers per 100 inhabitants of the LDCs surpassed that of the developed countries. One notable break with the past is that with opening up of the developing economies and widespread sectoral reforms, catching up process has become faster. Developing countries with liberal policies have much better opportunity to leapfrog than before. Mobile experience of the low-income countries bears testimony to this process. India is a participant in this global process. India has proven its dominance as a technology solution provider and experiencing a revolution in the telecommunication sector.

\section{Reference:}

[1]. BSNL. (2003). NATIONAL TELECOM MUSEUM. Retrieved 01 11, 2010, from BSNL: http://www.mp.bsnl.co.in/tel/h4p8b.htm

[2]. BSNL. (n.d.). About Us. Retrieved December 09, 2009, from Bharat Sanchar Nigam Ltd: http://www.bsnl.co.in/about.htm

[3]. Bsnl. (n.d.). IMPORTANT EVENTS IN HISTORY OF TELECOMMUNICATION. Retrieved 12 12, 2009, from BSNL: http://www.bsnl.co.in/150/important_events.htm

[4]. ET. (2009, November 21). Operators add record $16.67 \mathrm{mn}$ subscribers in Oct: TRAI. The Economic Times .

[5]. IANS. (2009, July 30). India adds $11.9 \mathrm{mn}$ telecom subscribers in June. The Economic Times .

[6]. Kaushik, M. (2007, November 18). Telecom base crosses 250 million. Business Today.

[7]. Mitra, K. (2009, 12 11). Zero Phone tariffs anyone? Business Today .

[8]. Mohanasundaram, V. Significant Contribution of Telecommunication Sector. In P. G. P. Jagadish Gandhi, Services sector in the Indian Economy. New Delhi: Deep \& Deep Publications Pvt. Ltd.

[9]. Report, E. S.-2. (2009). Energy, Infrastructure and Communications-TELECOMMUNICATIONS. Ministry of Finance, Government of India.

[10]. Shinde, R. (2009, March 18). GSM, CDMA players maintain subscriber growth momentum. The Economic Times .

[11]. Sprague, C. (2008). Telecommunications in Business. Research Starters Business , 1-3.

[12]. Thomas, P. (2007). Telecom Musings: Public Service Issues in India. Emerald Group Publishing Limited , $97-107$.

[13]. TRAI. (2009). Telecom Subscription Data as on 30th Sep-2009. TRAI. New Delhi: TRAI.

[14]. TRAI1. (2006, September 12). Monthly Growth in Telecom Subscribers Inches towards 6 Million Mark.

[15]. TRAI2. (2006). The Indian Telecom services Performance Indicator Report for the Quarter ending September 2005. New Delhi: Telecom Regulatory Authority of India, GOI.

[16]. Tso, C.-D. (2002, June). Evolution of Cellular Telecom Equipment Industry: Technology-Driven or Policy-Stimulated. Indian Journal of Economics and Business , 111-33. 